\title{
MJMR DEVELOPMENT OF GUIDELINES FOR OBSERVER TUBERCULOSIS PATIENTS IN TASIKMALAYA CITY, INDONESIA
}

\author{
Nina Pamela Sari ${ }^{1 *}$, Neti Juniarti ${ }^{2}$, Desy Indra Yani ${ }^{2}$ \\ ${ }^{I}$ Faculty of Health Science, University of Muhammadiyah Tasikmalaya, Iindonesia \\ ${ }^{2}$ Faculty of Nursing Padjadjaran University, Bandung, Indonesia \\ Corresponding Author E-mail: ninapamelasari@gmail.com
}

\begin{abstract}
Tuberculosis (TB) now still become the world's health problems. The incidence of TB was also increasing in Indonesia, resulting in Indonesia currently ranks third in the world number of TB patients so that efforts from the government and various parties was very important to tackle TB in Indonesia. The high prevalence of TB in Indonesia was a challenge for health workers to cope with TB. Observer TB was the forefront of TB treatment settlement, so a guide for the observer was required to complete its tasks thoroughly. However, there are no comprehensive TB guidelines yet in Tasikmalaya City so qualitative research to explore how the development of observer guidelines was needed. The design of this study is descriptive explorative qualitative research with indeepth interview to participants who understand the development of observers guidelines for TB patients. Selection of participants using purposive sampling technique, based on inclusion criteria found as many as twelve participants. The research instrument used semi-structured interview guide which was done with indepth interview technique, one month research time, data analysis using (Braun and Clarke Theory 2006). The research results obtained three themes, namely: increasing the problem of TB prevention in Tasikmalaya City, optimizing the task of observers, and comprehensive guidance for optimizing the role of observers. The conclusions of this study were the findings based on the participants' opinions on the guidelines of comprehensive drug swallowing supervisors including explanation of observers tasks, TB information for observers, ways of preventing and handling TB, handling side effects, as a remedy for taking medicine with check list and when to take medication. The guidelines according to the participants was packaged in a simple, not complicated but cover all what is in the observers guidelines.
\end{abstract}

\section{Keywords : Guidelines, Observers, Tuberculosis}

\section{INTRODUCTION}

This research was motivated by the observations of researchers when discussing with one of the TB programmers (Tuberculosis) in one of the health centers in the City of Tasikmalaya. At that time there was a TB patient who was delivered by the observer (Drug Swallowing Supervisor) to take medicine and control to the health centre, the patient received the drug for a period of treatment for one month, the patient entered the fourth month of treatment, then the programmer recorded and marked the date of taking the drug into TB card 01 for the next month. During the patient's treatment period, the TB programmer gets information about complaints, the patient's condition and side effects of OAT (Anti-Tuberculosis Medication) from patient reports directly or through observer when controlling or taking further medication to the puskesmas.

Treatment of TB patients requires rational use of OAT by health workers to achieve high cure rates and adequate support from various parties for TB patients and the role of observer. The observer should be done by people who understand the principles of TB treatment. Limited number of health workers so that observer was needed from the community, namely family members. The observer from family members gives the greatest influence on the treatment compliance of TB sufferers when controlled with a good level of observer knowledge and or close family relations of observer with TB sufferers (Sidy, 2012). Research conducted by (Okanurak et al. 2007) in Bangkok shows that TB 
treatment completion rates are significantly greater when supervisors are carried out by family members, compared to supervisors by health professionals. In Nepal, supervisors by family members are more effective than by health professionals (Newell et al., 2006).

The increasing number of TB incidents in Indonesia and the many factors that cause TB non-adherence so that important government efforts are needed to address them. The role of the government in tackling and reducing the incidence of Tuberculosis is by Directly Observed Therapy Shortcouse (DOTS). Based on the results of interviews with TB supervisor representatives in the province of West Java and TB program holders in the City of Tasikmalaya so far the observer TB in carrying out their duties has not been provided with a special handbook on observer duties. However, the observer task descriptions have been regulated by the government and are listed in the National Strategy for TB Control in Indonesia 2010-2014, National Guidelines for TB Control in 2014, and Minister of Health Regulation number 67 of 2016 concerning TB Control. While from the private sector in 2009 a TB Handling Program Cadre Pocket Book was published in collaboration with USAID, CARE International Indonesia, and the Directorate General of Disease Control and Environmental Health, MOH RI in 2009, but its use has not been carried out simultaneously in all regions in Indonesia .

The guideline was a systematic development based on a statement of research results consisting of service providers, service recipients and other stakeholders to make a decision about health interventions carried out appropriately (WHO, 2003). Guidelines can be in the form of protocols, best practices, algorithms, consensus statements, expert committee recommendations and integrated care through pathways (WHO, 2003). The need for guidelines based on contributing to the development of methodology as the most powerful basis for science-based guidelines (Gyorkos 1994, Woolf 1996, Shekelle 1999, SIGN 1999, NHRMC 2000 in WHO 2003).

This research was expected to explore the need for developing guidelines for observer TB, especially in the city of Tasikmalaya, with the results of the study expected to be made as further recommendations for the preparation of observer task guidelines for TB patients.

\section{METHODOLOGY}

The research design used in this study was qualitative research because it emphasizes the effort of inquiry in revealing situations that occur naturally and comprehensively (Prastowo, 2011). This research was conducted to see the development of guidelines in more detail which emphasizes the critical aspects of detail and forms the basis of the paradigm in this research. The approach used in this research was descriptive qualitative, which was to explore in-depth competent participants and understand the development of guidelines for the swallowing of drugs for tuberculosis patients. Participants in the study consisted of observers and stakeholders who had rich information about developing observer guidelines in tuberculosis patients. Information about patient experience, health workers in implementing observer guidelines, as suggested by (Guest, Bunce and Johnson 2006) using twelve participants was sufficient in research aimed at understanding general perceptions and experiences.

The inclusion criteria in this study were TB program holders in provinces with experience in their fields for at least one year; holders of TB programs in cities with experience in their fields for at least one year; TB program holders in health centre with experience in their fields for at least one year; academic health experts on TB who are experienced in their fields for at least one year; medical experts or TB medical practitioners who have experienced in accordance with their fields for at least one year; TB expert researchers with experience in the field for at least one year; TB observer who has accompanied TB patients for at least one month's treatment.

Research through a qualitative approach was carried out in a natural setting of conditions that researchers want to know as an instrument. When in depth interviews the research instrument used is the researcher himself with interview guides recorded with a tape recorder and field note assistance prepared during the interview process. In this study the target research period for one month or until saturated data was obtained. Analysis of the data in this study uses the theory of Braun and Clarke, 2006 which includes 6 stages. Data validity was needed so that the information obtained in the study is valid. 
Validity was done by checking or checking the data that has been obtained. According to (Moleong, 2006), there are four criteria used in data validity, namely the degree of trust (creadibility), dependability, transferability, and certainty (confirmability). Ethical considerations include aspects of autonomy, benefit, non-malefficiency, justice, fidelity and veracity.

\section{RESULT}

From the results of the study found three major themes, namely the increasing problem of TB control in the City of Tasikmalaya, optimizing the task of observer and comprehensive guidelines to optimize the task of observer. Of the three major themes are grouped into thirteen sub-themes related to the development of guidelines for the Supervision of Drug Swallowing in the City of Tasikmalaya. To facilitate the presentation of research data the themes and sub-themes are arranged in the form of a theme map chart contained in the following chart:

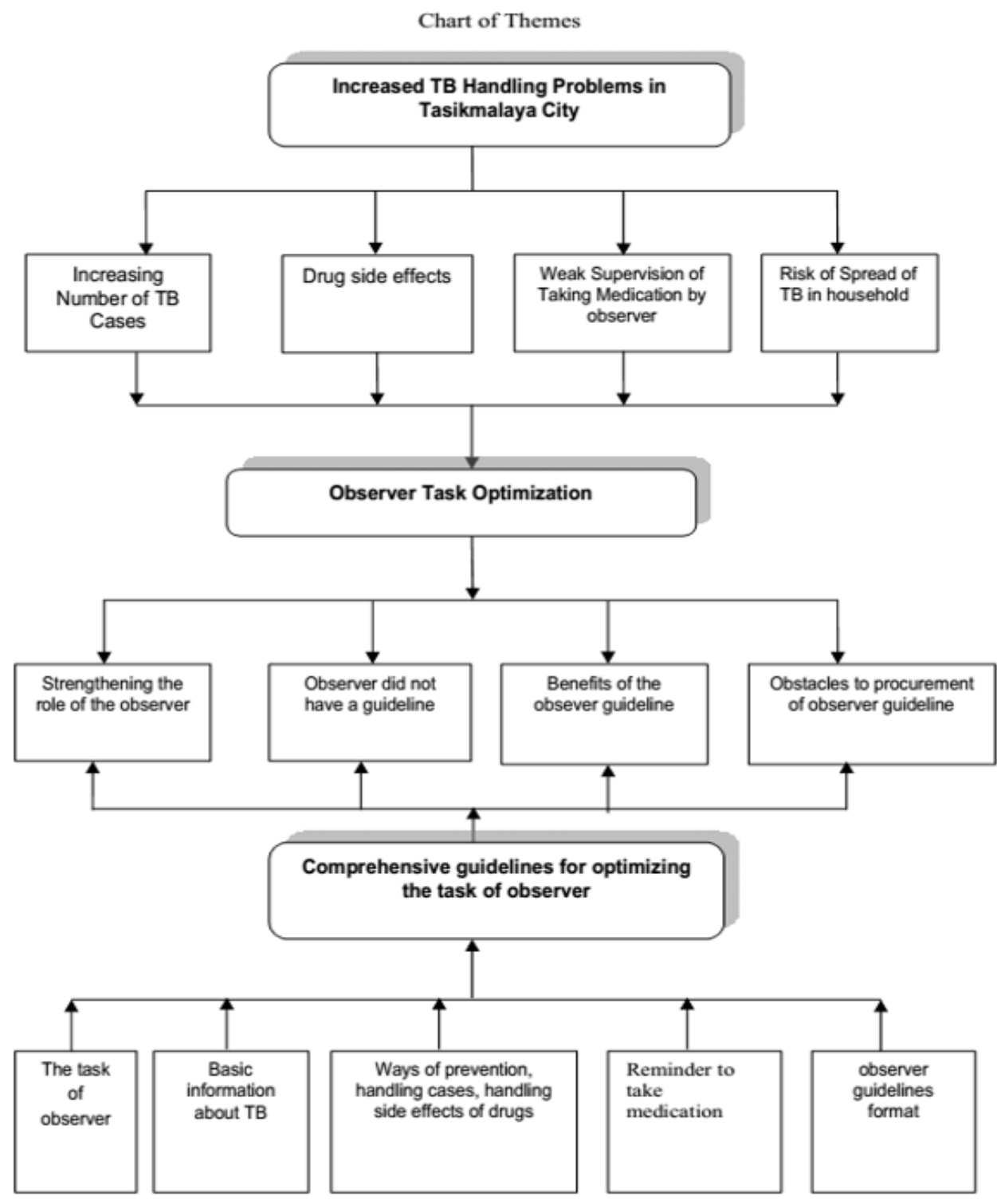

Figure 1: The presentation of research data the themes and sub-themes are arranged in the form 


\section{DISCUSSION}

This sub-chapter will discuss the results of research that are connected with theory, evidence-based, and the results of previous research on the Development of Guidelines for the Supervision of Swallowing Drugs for Tuberculosis Patients in Tasikmalaya City.

\section{Increasing TB control problems in the City of Tasikmalaya}

TB is currently still quite high in the City of Tasikmalaya and even in the province of West Java when compared to other provinces, many factors influence the high prevalence of TB in the City of Tasikmalaya, the handling of TB cases not only involves the government sector and community participation but also the private sector. According to participants, the national TB health indicator in the city of Tasikmalaya was less than the national standard, this was due to case reporting from hospitals or private health services, because many TB patients were reported missing to follow up or drop out. The practice patterns of TB case management in private health services in Indonesia still do not use national guidelines, many medical staff do not understand about ISTC and have not yet attended ISTC training (Mahendradhata, 2015).

TB treatment takes a long time ranging from 6-8 months, this condition was quite susceptible to the level of compliance of TB patients in undergoing treatment if not properly monitored, in addition to the length of treatment there are also many factors that affect TB adherence in treatment. This was in line with factors that influence drug withdrawal patients in Kenya that longterm medication adherence is a multidimensional phenomenon, with determinants including: socioeconomic factors, health team factors, factors related to the health system, conditions, therapy and patients (Muture et al., 2011).

TB cases these were increasing from year to year in the City of Tasikmalaya were also affected by reports from hospitals to the Tasikmalaya City health office, because many TB patients did not continue treatment or patients move to other places but did not report so many cases drop out. In India, communication strategies such as training, disseminating information on policy changes and one-on-one dialogue with private practitioners can eliminate misunderstandings in TB case reporting. Trust building strategies such as providing feedback on the joint record of the private sector, visiting health workers or liaison private doctors can ensure compliance with public health activities (Philip, 2015).

TB patients have the challenge of being able to complete TB treatment, so TB or observer patients must understand the side effects caused by TB drugs. The inadequacy of patient knowledge about TB was the biggest factor causing failure to treat $\mathrm{TB}$ patients in Naoirobi, Kenya. Knowledge needs of patients are needed, especially about the possible side effects that will arise when TB patients consume OAT and how to overcome them (Muture et al., 2011).

One of the tasks of the observer was recording or monitoring TB patients to ingest drugs in observer monitoring cards. Likewise, in the Sigli, Pidie district, Aceh, there were still many observer who did not recording drugs when taken by TB patients, most observer mark the date on the calendar posted at home (Hadifah, 2014).

Supervision and monitoring carried out by observer on TB patients when swallowing drugs at this time in the City of Tasikmalaya were still mostly orally. Some observers have been given observer pocket books or patient observation sheets to swallow drugs, but there were still many observers that have not checked or documented the observer's work that has been done. This condition was in accordance with the causes that influence the increase in TB burden as stated in the explanation of the Minister of Health regulation No. 67 of 2016 concerning Tuberculosis Control, was not monitoring treatment and not recording and reporting standards. This was a consideration of the need for the development of a guidebook that is effectively efficient for the observer. Research results in China show that the problem that still remains to control tuberculosis in rural China is controlling efforts in vulnerable populations and encouraging local health care providers by adopting innovative practices in local contexts based on national guidelines (Bele et al., 2014)

House contact with active TB cases was a high risk for family members who can get $\mathrm{TB}$, so rapid $\mathrm{TB}$ case investigation was needed to control the spread of TB cases. Despite the fact that home contact investigations are rarely carried out in developing countries due to the limited number of officers, the high workload of health 
workers, and limited resources (Tornee, 2005).

The observer's duty in addition to reminding TB patients to re-sputum check also motivates family members who were at home to check sputum especially on family members who are still children or family members who have clinical symptoms toward TB disease. Every pulmonary TB patient has the potential to transmit the disease to fifteen new patients per year (WHO, 2006).

\section{Optimization of observer Tasks}

At present observer tasks in the field vary in carrying out their duties so that the optimization of the role of observer has not been fully achieved. Some participants expressed the importance of TB case screening or active TB case finding through the role of the observer, so that the role of the observer could be carried out optimally according to its task. The observer can motivate the household contact to have sputum checked so that it was known immediately if there was TB transmission to other family members and can be quickly dealt with by health workers through observer involvement. This was in accordance with the rules set forth in the Regulation of the Minister of Health of the Republic of Indonesia number 67 of 2016 in paragraph 4 regarding the discovery and handling of TB cases article 11 paragraph 1 : TB cases are found actively and passively, paragraph 2: active TB case discovery as referred to in paragraph (1) is done through: a. Investigation and examination of contact cases; b. Mass screening especially in vulnerable groups and at risk groups; and c. Screening in special situation conditions (Ministry of Health, 2016).

Based on the expression of all participants observer said that participants have not examined the sputum of family members in household contact with TB patients. Domestic contact with TB patients is very potential to be able to transmit TB disease resulting in a higher rate of high TB incidence, so the need for home contact investigations to reduce TB cases. This was in line with research in Vietnam that through investigation of household contact can reduce the transmission of disease that takes place in the community (Fox, 2012).

According to participants at this time the number of health workers in the community who handle the TB problem is still limited in number so that in the supervision of patients taking TB patients the drug was helped by the role of the observer from the family. This was in line with qualitative studies of TB patients who receive support and care from families showing increased adherence to therapy and acceptance of care (Maciel et al., 2003). In line with research conducted in Brazil that observer from family members proved effective in the success of TB treatment (Maciel, et.al., 2010). Family members are good supervisors and can increase TB patient compliance in adherence and increase cure rates (Muniz, 2002; Newel, 2006; and Thiam, 2007).

In Nepal, observer costs from families are lower compared to observers from cadres or volunteers in the community (Mirzoev et al., 2008). In Uganda the implementation of a community-based DOTS strategy offers patients the choice of observer during treatment therapy. The results showed an increase in the success of TB treatment increased from $56 \%$ to $74 \%$ (Adatu, 2003). observer by family members was chosen by 94 patients (96\%) of the 98 TB patients studied in Brazil, with a cure rate of $99 \%$ so that observer from family members was proven to be most effective at a lower cost (Maciel et.al., 2008). In line with in India, Gujarat, that DOT carried out by family members was not inferior to the DOT given by non-family members among new TB cases in children and can achieve international targets for treatment success (Dave, 2016).

According to the participants that the observer could come from any group, in principle the person appointed to be the observer was the person who was most concerned with the patient's condition. This was in line with research conducted in Malawi when patients choose their own observer showing the results that observer was proven to increase the success rate of TB treatment (Nyirenda, 2003).

The observer in carrying out their duties requires extra attention and time so that the work performed gets optimal results when assisting and supervising TB patients running treatment programs. This was in line with research in India that observer when carrying out their duties in directly supervising patients swallowing drugs can not be done optimally due to DOT-provider factors, because it takes the availability of time when conducting direct supervision of swallowing drugs, plus the presence of stigma and adverse event treatments ( Benbaba, 2015). 


\section{Comprehensive Guidelines for Optimizing the Role of observer}

In Tasikmalaya City every TB patient has a observer designated by the patient and known by the health worker. Based on participant expressions and the results of previous studies have shown that the role of observer was indeed effective in monitoring TB patients completing treatment. But as expressed by participants that in carrying out the role of the observer there are those that are already suitable and some were not optimal. So to optimize the role of observer according to participants, it is necessary to have a reminder tool or guidelines for observer. This was also expressed by several participants about the benefits of having guidelines for observer with various content components in it.

TB observer guidelines according to participants can be useful in monitoring patients swallowing drugs because these guidelines can be used as a reminder to take medication. According to participants also that the observer must understand about their duties as observer, know about information about TB, how to prevent and how to control TB so that it can inform others around his house. In addition, according to participants that the observer must also know how to cope with side effects, when to return to the health worker to take drugs as well as bring patient control, even the observer can motivate family members who contact at home to check sputum. So that these comprehensive guidelines according to participants are needed in watching patients swallow TB drugs.

These comprehensive observer guidelines cover the cognitive, psychomotor and affective domains. The cognitive domain when observer understands their duties, understands TB information, knows how to prevent and control TB, and knows how to deal with side effects. The psychomotor domain can be seen when the observer can monitor the TB patient swallowing the drug and continue to check the TB guidelines. The affective domain was carried out by the observer when the observer was able to motivate family members to contact household to check sputum. In line with research that has been carried out in measuring the integration of a reference comprehensively, it can be achieved if the evaluation includes cognitive, psychomotor and affective domains (Arthur, 2013).

Based on the opinions expressed by participants that the observer guidelines should be able to cover all elements of observer tasks, but participants also said that the guidelines can still be made as simple as possible in appearance. This was in accordance with the guidelines developed by (Suyasa, 2013) regarding fecal incontinence self-care guidelines, for the print appearance of a guideline we recommend using a sanserif type font (Arial), a minimum font size of 10, use a wide margin, a white base, use a short sentence decomposition so easy to understand for readers, use effective illustrations, use the right colors, namely warm colors like yellow, orange, red and use a type of opaque paper that was not shiny for easy reading. Another participant said it was more convenient to record the patient's schedule for taking medication and when to return to the health worker recorded in the calendar. This was in line with the opinion of (Hadifah, 2014) that there are still many observers in Aceh who do not record drugs when TB patients ingest drugs, most observers are more comfortable to mark the date of taking TB patients' drugs on calendars posted at home. (Resmyta, 2013), in his scientific writing has also made an idea about the Medication Drinking Calendar (KMO). The calendar was created as a reminder sheet at the same time can motivate TB patients, there were guidelines for TB treatment and side effects, but there has been no filling in to check the side effects of drugs, notes about the date when taking drugs, sputum check notes and observer notes motivate family members of household contacts to check sputum.

In line with what Cahyani has done, 2015 which offers Smart Calendar media in monitoring the compliance of TB patients taking drugs, these scientific papers use the literature review method by analyzing theories. The smart calendar was like a torn calendar as a sign of the day the TB patient has passed the time of treatment, the torn day sheet was reassembled for pasting with a paper stick, in addition there was also a check list box filled after the TB patient has finished taking medication. But in this smart calendar not yet equipped with a record of side effects of drugs, observer notes motivate family members of household contacts to check sputum nor was there a record for when to seek treatment again and when to check sputum again.

Indonesia was a developing country that currently includes a country that has a high disease burden with the third rank in the world for TB cases, it was very 
important to make a variety of innovations in TB control. The Android-based Drugs Consumtion Calendar (DCC) application has been developed by Amelia, 2016 in Yogyakarta, which in the application provides a calendar to remind TB patients to take medication, then also the availability of information on how to calculate the dosage of taking medication adjusted to the patient's body weight. However, the use of this application was still limited for category I TB patients, then this application also has not been tested directly to users, namely TB patients due to lack of time, this application also still uses keywords to be opened and continue to the next stage of treatment.

In developed countries, various studies have been developed to monitor compliance with TB patient treatment. In Australia, home video observations by means of delivering patient-centered resources have proven to be more efficient in observing TB patients. More cost effective when compared to drive-around service (Wade, 2012). In Canada, to monitor the compliance of TB patients taking drugs using the Ingestible sensor-based system. This system has high accuracy so that it can detect the time the patient is taking medication, drug side effects. This tool has a low risk for users, and has a high patient acceptance. This system has the potential to confirm specific medication adherence on a dose-by-dose basis and can be added with wireless Wireless Observer Therapy (WOT) to monitor TB treatment as a substitute for DOT (Belknap, 2013).

\section{CONCLUSIONS}

Based on the results of research and discussion, the general conclusion in this study is the findings obtained from this study based on participants' opinions that comprehensive drug swallowing guidelines include an explanation of the main tasks of the observer, information on TB for observer, ways of preventing and managing TB, handling side effects, as a reminder to take medication by checking the list, when to take medication and motivating family members to check phlegm. The guideline was in the opinion of participants to be packaged simply, not complicated but includes all that is in the observer guidelines.

\section{SUGGESTION}

The results of this study were expected to be considered as recommendations for recommendations in preparing a guideline for swallowing drugs for tuberculosis patients, because of the results of this study found comprehensive guidelines for optimizing the role of observer according to participants. The findings obtained can be used as a basis for further research in making a guide for observer so that the role of observer becomes more optimal in tackling tuberculosis in Indonesia.

\section{ACKNOWLEDGEMENT}

This research was supported by Universitas Muhammadiyah Tasikmalaya, my lecture and my supervisor Mrs Neti Juniarti, Mrs Desy Indra Yani, who provided expertise that greatly assisted the research.Thank you also to all participants who have agreed to be respondents in this study.

\section{CONFLICT OF INTERESTS}

The authors declare that they have no conflict of interest.

\section{REFERENCES}

Adatu, F., Odeke, R., Mugenyi, M., et al. (2003). Implementation of the DOTS strategy for tuberculosis control in rural Kigoba District, Uganda, offering patients the option of treatment supervision in the community, 1998-1999, International Journal Tuberculosis Lung Disease, 7(9 suppl 1):S63-S71

Amelia, F., Nahrin, S. N., Permatasari, D. A., \& Suryani, F. (2016, September). Aplikasi Kalender Minum Obat TBC Berbasis Adroid. In Seminar Nasional Informatika Medis (SNIMed) (No. 5).

Anuwatnonthakate, A., Limsomboon, P., Nateniyom, S., Wattanaamornkiat, W., Komsakorn, S., Moolphate, S., Varma, J. K. (2008). Directly observed therapy and improved tuberculosis treatment outcomes in thailand. PLoS One, 3(8) doi:http://dx.doi.org/ 10.1371/journal.pone.0003089

Arthur. (2013). Pengukuran Acuan Terpadu (PAT) dalam Mengukur Kompetensi pada Ilmu-Ilmu Terapan (Kejuruan), http://educ.utm.my/wpcontent/uploads/2013/11/53.pdf mengukur PAT kompetensi terapan

Bele, S., Jiang, W., Lu, H., You, H., Fan, H., Huang, L., . 
. Wang, J. (2014). Population aging and migrant workers: Bottlenecks in tuberculosis control in rural china. PLoS One, 9(2), e 88290. doi:http://dx.doi. org/10.1371/ journal. pone. 0088290

Belknap R, Weis S, Brookens A, Au-Yeung KY, Moon G, et al. (2013) Feasibility of an Ingestible SensorBased System for Monitoring Adherence to Tuberculosis Therapy. PLOS ONE 8(1): e53373. https://doi.org/10.1371/journal.pone.0053373

Benbaba, S., Isaakidis, P., Das, M., Jadhav, S., Reid, T., \& Furin, J. (2015). Direct observation (DO) for drug-resistant tuberculosis: Do we really DO? PLoS One, 10(12) doi:http://dx.doi.org/10.1371/ journal.pone. 0144936

Bhawnani, D., Verma, N., Tiwari, A., \& Bandhi, G. (2014). Assessment of knowledge and practice of tuberculosis health visitors and health workers under revised national tuberculosis control programme in raipur district of chhattisgarh state. National Journal of Medical and Dental Research, 2(3), 18-24. Retrieved from https://search. proquest. com/docview/ 1556081460 ? accountid $=62690$

Bungin, B. (2008). Sosiologi Komunikasi (Teori, Paradigma, dan Discourse Teknologi Komunikasi di Masyarakat). Jakarta: Kencana Prenada Media Group.

Cahyani, M., A., (2015). Kalender Pintar : Solusi Inovatif Pengingat Kepatuhan Minum Obat pada Penderita TB, UNIVERSITAS JEMBER, https://docslide.net/documents/kalender-minumobat-penderita-tbc.html

Comolet, T. M., Rakotomalala, R., \& Rajaonarioa, H. (1998). Factors determining compliance with tuberculosis treatment in an urban environment, Tamatave, Madagascar. The International Journal of Tuberculosis and Lung Disease, 2(11), 891-897.

Dave, P. V., Shah, A. N., Nimavat, P. B., Modi, B. B., Pujara, K. R., Patel, P., . . Kumar, A. M. V. (2016). Direct observation of treatment provided by a family member as compared to non-family member among children with new tuberculosis: A pragmatic, noninferiority, cluster-randomized trial in gujarat, india. PLoS One, 11(2) doi:http://dx.doi.org/ 10.1371/ journal.pone. 0148488
Departemen Kesehatan Republik Indonesia, (2009). Buku Saku Kader Program Penanggulangan TB, Direktorat Jenderal Pengendalian Penyakit dan Penyehatan Lingkungan, Departemen Kesehatan Republik Indonesia.

El Arifeen, S., Christou, A., Reichenbach, L., Osman, F. A., Azad, K., Islam, K. S., . . Peters, D. H. (2013). Community-based approaches and partnerships: Innovations in health-service delivery in bangladesh. The Lancet, 382(9909), 2012-26. doi:http://dx.doi.org/10.1016/S01406736(13)62149-2

Fox, G. J., Nhung, N. V., Sy, D. N., Lien, L. T., Cuong, N. K., Britton, W. J., \& Marks, G. B. (2012). Contact investigation in households of patients with tuberculosis in hanoi, vietnam: A prospective cohort study. PLoS One, 7(11) doi:http://dx.doi. org/10.1371/journal.pone.0049880

Getahun, B., \& Nkosi, Z. Z. (2017). Satisfaction of patients with directly observed treatment strategy in addis ababa, ethiopia: A mixed-methods study. PLoS One, 12(2) doi:http://dx.doi.org/ 10.1371/ journal.pone.0171209

Hadifah, Z. (2015). Pemenuhan Tugas Pengawas Menelan Obat (observer) Bagi Penderita Tuberkulosis (TB) sebagai Indikator Penyakit Menular di Puskesmas Kota Sigli Kabupaten Pidie. Jurnal Sel, 1(1), 17-23.

Jaiswal, A., Singh, V., Ogden, J. A., Porter, J. D. H., Sharma, P. P., Sarin, R., \& Jain, R. C. (2003). Adherence to tuberculosis treatment: lessons from the urban setting of Delhi, India. Tropical Medicine \& International Health, 8(7), 625-633.

Kangovi, S., Mukherjee, J., Bohmer, R., \& Fitzmaurice, G. (2009). A classification and metaanalysis of community-based directly observed therapy programs for tuberculosis treatment in developing countries. Journal of Community Health, 34(6), 506-13. doi:http://dx.doi.org/ 10.1007/s10900-009-9174-4

Kementrian Kesehatan Republik Indonesia, (2011). Strategi Nasional Pengendalian TB DI Indonesia 2010-2014. Direktorat Jenderal Pengendalian Penyakit dan Penyehatan Lingkungan, Kementrian Kesehatan Republik Indonesia. 
Kementrian Kesehatan Republik Indonesia, (2013). Riset Kesehatan Dasar 2013, Badan Penelitian dan Pengembangan Kesehatan, Kementrian Kesehatan Republik Indonesia.

Kementrian Kesehatan Republik Indonesia, (2014). Pedoman Nasional Pengendalian Tuberkulosis. Direktorat Jenderal Pengendalian Penyakit dan Penyehatan Lingkungan, Kementrian Kesehatan Republik Indonesia.

Kementrian Kesehatan Republik Indonesia, (2016). Peraturan Menteri Kesehatan Republik Indonesia nomor 67 tahun 2016 tentang Penanggulangan Tuberkulosis.

Kementrian Kesehatan Republik Indonesia, (2016). Infodatin Tuberkulosis Temukan Obati Sampai Sembuh. Pusat Data dan Informasi Kemetrian Kesehatan repoublik Indonesia.

Lei, X., Huang, K., Liu, Q., Yong-Feng, J., \& ShengLan, T. (2016). Are tuberculosis patients adherent to prescribed treatments in china? results of a prospective cohort study. Infectious Diseases of Poverty, 5doi:http://dx.doi.org/10.1186/s40249016-0134-9

Lismayanti, L. (2011). Pengalaman Hidup Penderita Filariasis di Kota Tasikmalaya, Universitas Padjajaran Fakultas Ilmu Keperawatan Program Magister Ilmu Keperawatan, Bandung

Maciel, et a.1, (2008). "Directly Observed Therapy Using Home-Based Supervisors for Treating Tuberculosis in Vitória, Brazil"

Mahendra, (2006) Faktor - faktor yang Berhubungan dengan Penemuan Kasus TB di Bali, http://download.portalgaruda.org/article.php?artic le $=17939 \& \mathrm{val}=1114[6 / 3 / 2017]$

Mahendradhata, Y., Lestari, T., Probandari, A., Lucia, E. I., Burhan, E., Mustikawati, D., \& Utarini, A. (2015). How do private general practitioners manage tuberculosis cases? A survey in eight cities in indonesia. BMC Research Notes, 8 Retrieved from https://search.proquest.com/docview/ 1779874613 ? accountid $=62690$

Ministry of Health \& Family Welfare, (2010). Revised National Tuberculosis Control Programme, Central TB Division, Directorate General of Health
Services.

Moleong, L.J. 2007.Metodologi Penelitian Kualitatif. Edisi Revisi. Bandung. Rosda.

Moosazade, M., Jamshidi, M., Amiresmaili, M., \& Nezammahalleh, A. (2012). A comparison of directly observed therapy and self-administered therapy strategies in treatment of pulmonary tuberculosis: A cohort study in north of Iran. Middle-East JSci Res, 11(7), 873-880.

Muture, B. N., Keraka, M. N., Kimuu, P. K., Kabiru, E. W., Ombeka, V. O., \& Oguya, F. (2011). Factors associated with default from treatment among tuberculosis patients in nairobi province, kenya: A case control study. BMC Public Health, 11, 696. doi:http://dx.doi.org/10.1186/1471-2458-11-696

Newell, J., N., Baral, S., C., Pande, S., B., Bam, D., S., Malla, P., (2006). Family member DOTS and community DOTS for tuberculosis control in Nepal: cluster-randomised controlled trial, Lancet, 2006;367(9514):903-9. DOI:10.1016/S01406736(06)68380-3

Newell, J. N., Pande, S. B., Baral, S. C., Bam, D. S., \& Malla, P. (2004). Control of tuberculosis in an urban setting in nepal: Public-private partnership. World Health Organization.Bulletin of the World Health Organization, 82(2), 92-8. Retrieved from http://search. proquest.com/ docview/ 229544131 ? accountid $=48290$

New Jersey Medical School, National Tuberculosis Center, (2003). Guidelines for Collaborating with Community Physicians, New Jersey Medical School.

Nyirenda, T., E., Harries, A., D., Gausi, F., et al. Decentralisation of tuberculosis services in a urban setting, Lilongwe, Malawi, International Journal Tuberculosis Lung Disease, 2003; 7(suppl):S21S29

Obermeyer, Z., Abbott-Klafter, J., \& Murray, C. J. L. (2008). Has the DOTS strategy improved case finding or treatment success? an empirical assessment. PLoS One, 3(3) doi:http:// dx.doi.org/ 10.1371/journal.pone.0001721

Otu, A. A. (2013). Is the directly observed therapy short course (DOTS) an effective strategy for 
tuberculosis control in a developing country? Asian Pacific Journal of Tropical Disease, 3(3), 227-231.

Philip, S., Isaakidis, P., Sagili, K. D., Meharunnisa, A., Mrithyunjayan, S., \& Kumar, A. M. V. (2015). "They know, they agree, but they don't do"- the paradox of tuberculosis case notification by private practitioners in alappuzha district, kerala, india. PLoS One, 10(4) doi:http://dx.doi.org/10.1371/ journal.pone. 0123286

Prado, T. N. D., Wada, N., Guidoni, L. M., Golub, J. E., Dietze, R., \& Maciel, E. L. N. (2011). Costeffectiveness of community health worker versus home-based guardians for directly observed treatment of tuberculosis in Vitoria, Espirito Santo State, Brazil. Cadernos de saude publica, 27(5), 944-952.

Resmyta, Kingkin. (2013). Kalender Minum Obat (KMO) SebagaiSarana Pendukung Strategi DirectlyTreatment Shortcourse (DOTS) Dalam U s a a P e n anggulangan Penyakit Tuberculosis(TBC) di Indonesia UNIVERSITAS LAMBUNG MANGKURATFAKULTAS K E D OKTER A N P R O GR A M S T UD I PENDIDIKAN DOKTER BANJARMASIN, https://id.scribd.com/document/172094127/Kalen der-Minum-Obat-penderita-tbc

Sidy, N., Y., (2012). Analisis Pengaruh Peran Pengawas Menelan Obat dari Anggota Keluarga terhadap Kepatuhan Pengobatan Penderita Tuberkulosis di Kota Pariaman Tahun 2010-2011, Universitas Indonesia Fakultas Kesehatan Masyarakat Program Studi Pasca Sarjana Ilmu Kesehatan Masyarakat, Depok

Sis, H. Y., Jannati, A., AsghariJafarabadi, M., Ebrahimi-kalan, M., Taheri, A., \& Koosha, A. (2014). The effectiveness of family-based DOTS versus professional-family mix DOTS in treating smears positive tuberculosis. Health Promotion Perspectives,4(1), 98-106. Retrieved from, http://search.proquest.com/docview/1617792422? accountid $=48290$

Steffen, R., Menzies, D., Oxlade, O., Pinto, M., Castro, A. Z., Monteiro, P. \& Trajman, A. (2010). Patients' costs and cost-effectiveness of tuberculosis treatment in DOTS and non-DOTS facilities in rio de janeiro, brazil. PLoS One, 5(11) doi:http:// dx.doi.org/10.1371/journal.pone.0014014, http:// search.proquest.com/docview/1292207792/555E0 D5015164E12PQ/4?accountid $=62690$

Suyasa, I., G., D., (2013). Develompent of a Self-care Guideline of Faecal Incontinence for Communitydwelling Older People in Indonesia, Disertasi, School of Nursing and Midwifery, Faculty of Health Sciences Flinders University, Adelaide, Australia

Thiam, S., LeFevre, A., M., Hane, F., Ndiaye, A., Ba, F., Fielding, K.,L., et al. (2007). Effectiveness of a strategy to improve adherence to tuberculosis treatment in a resource poor setting: a cluster randomized controlled trial. JAMA, 2007;297(4): 380-6. DOI:10.1001/jama.297.4.380

Turner, T., Misso, M., Harris, C., and Green, S. (2008). Development of evidence-based clinical practice guidelines (CPGs) : comparing approaches, BioMed Central, [online]. Available at http://www. implementationscience.com/content/3/I/45

Walley, J. D., M, A. K., Newell, J. N., \& M, H. K. (2001). Effectiveness of the direct observation component of DOTS for tuberculosis: A randomised controlled trial in pakistan. The Lancet, 357(9257), 664-9. Retrieved from http://search. proquest.com/docview/199025721 ?accountid $=48$ 290

Wade, V. A., Karnon, J., Eliott, J. A., \& Hiller, J. E. (2012). Home videophones improve direct observation in tuberculosis treatment: A mixed methods evaluation. PLoS One, 7(11) doi:http:// dx.doi.org/10.1371/journal.pone.005015 http:// search.proquest.com/docview/1351067644/F14C D0009BD246CAPQ/17?accountid $=62690$

World Health Organization, (2002). A Guide for Tuberculosis Treatment Supporters

World Health Organization, (2003). Guidelines for WHO Guidelines. In Global Program on Evidence for Health Policy World Health Organization

World Health Organization. (2010). The global planning to stop TB 2011-2015. Geneva, Switzerland: World Health Organization. 
World Health Organization. (2011). Ending TB in the South-East Asi Region:Regional Strategic Plan 2016-2020.

World Health Organization. (2010). Treatment of Tuberculosis Guidelines. Fourth Edition. Geneva, Switzerland: World Health Organization.

World Health Organization. (2014). International Standars For Tuberculosis Care, Diagnosis Treatment Public Health, Third Edition.

World Health Organization. (2016). Global Tuberculosis Report 2016. Geneva, Switzerland: World Health Organization.

Wysocki, A. D., Villa, T. C., Arakawa, T., Brunello, M. E., Vendramini, S. H., Monroe, A. A., \& Kritski, A. L. (2016). Latent tuberculosis infection diagnostic and treatment cascade among contacts in primary health care in a city of sao paulo state, brazil: Crosssectional study. PLoS One, 11(6) doi:http:// dx.doi. org/ 10.1371/journal. pone. 0155348
Yani, D. I. , Isaramalai, S. , Kritpracha, C. (2014). 'Effect of Family-Based DOTS Support Program on Adherence to Health Behaviors among Patients with Pulmonary Tuberculosis in Bandung, Indonesia'. World Academy of Science, Engineering and Technology, International Science Index, Medical and Health Sciences, 1(9), 146.

Zhang, H., Ehiri, J., Yang, H., Tang, S., \& Li, Y. (2016). Impact of community-based DOT on tuberculosis treatment outcomes: A systematic review and metaanalysis. PLoS One, 11(2) doi:http://dx.doi.org/ 10.1371/journal.pone.0147744

Zwarenstein, M., Schloeman, J. H., Vundule, C., Lombard, C. J., \& Tatley, M. (1998). Randomised controlled trial of self-supervised and directly observed treatment of tuberculosis. The Lancet, 352(9137), 1340-3. Retrieved from http://search. proquest.com/docview/198990637? accountid=48 290 